\title{
PENGARUH SPIRITUAL LEADERSHIP TERHADAP ORGANIZATIONAL COMMITMENT MELALUI CALLING DAN MEMBERSHIP PADA PT.ASURANSI TAKAFUL KELUARGA
}

\author{
Romi ilham (romi_ilham@perbanas.ac.id) \\ STIE Perbanas Surabaya
}

\begin{abstract}
Spiritual leadership is creation of values, attitude and behavior which is required to motivate one's selves and other by intrinsic motivation to achieve spiritual survival sense through calling and membership. Impact of spiritual leadership in developing relationship between leader and follower are value creation in harmony, empowerment of member and individual, increase psychology aspect and welfare until the organizational commitment is achieved. The objectives of the research are to gain knowledge regarding influence of spiritual leadership to organizational commitment through calling and membership. This research was conducted to 50 employees of PT Asuransi Takaful Kelvarga Marketing Office in East Java. Analysis technique used to test the hypothesis is Partial Least Square (PLS).Based on analysis result, we conclude that: (1) spiritual leadership is has significant influence to calling (2) spiritual leadership has significant influence to membership (3) calling has significant influence to organizational commitment and (4) membership has significant influence to organizational commitment.
\end{abstract}

Keywords: Spiritual Leadership, Organizational Commitment, Calling/Meaning, Membership.

\section{PENDAHULUAN}

Dewasa ini, dibutuhkan konsep-konsep kepemimpinan baru yang lebih inovatif untuk membawa organisasi bergerak menghadapi era persaingan baru. Jablonski (2007) mengatakan serangkaian proses yang saling berhubungan di dalam pengembangan spiritual yang menghasilkan sebuah cara kerja dengan manusia yaitu: pengembangan spiritual yang terdiri dari proses internal pencarian jati diri dan berbagai aspek pengembangan diri, proses berkesinambungan yang lebih dari satu tempat sentral, pengembangan hubungan kemasyarakatan dan personal yang sangat erat antara individu dengan orang lain, perolehan arti dan tujuan hidup dari individu, peningkatan pemahaman dan keterbukaan tentang sesuatu yang tidak berwujud dan kekuatan yang maha dashyat yang terjadi di antara eksistensi manusia dan pikiran rasional manusia. Senada dengan pernyataan Elgin \& LeDrew (1997), "There is a growing interest in the cultivation of expressiveness of soul and spiritual leadership capacities driving a global consciousness and interconnectedness".

Salah satu perhatian utama saat ini adanya gaya kepemimpinan baru yaitu kepemimpinan spiritual. Kepemimpinan Spiritual merupakan suatu kemampuan seorang pemimpin memberi dorongan, semangat, prinsip-prinsip terhadap hasil kerja, baik di tempat kerja maupun dalam lingkungan masyarakat (Fairholm, 1998:13). Sementara menurut Ashmos dan Duchon (2000) menyatakan bahwa pola pergerakan spiritualitas muncul di tempat kerja berhubungan dengan tradisi dari nilai-nilai yang berhubungan dengan agama dan ini merupakan kesan yang umum di lingkungan agama tetapi tidak umum di organisasi klasik dan manajemen. 
Kepemimpinan spiritual merupakan pembentukan values, attitude dan behavior yang dibutuhkan untuk memotivasi (intrinsic motivation) diri sendiri dan orang lain sehingga menimbulkan rasa kesejahteraan spiritual (spiritual survival) melalui calling dan membership (Fry, 2003). Penelitian ini dilakukan di kantor pemasaran PT. Asuransi Takaful Keluarga Jawa Timur dengan subjek penelitian para karyawan dari perusahaan tersebut. PT. Asuransi Takaful Keluarga sendiri merupakan sebuah perusahaan asuransi syariah, yang memiliki persamaan vision dan culture yang tergambarkan dari nilai-nilai perusahaan yang berdasar pada prinsip-prinsip syariah.

Pada kantor pemasaran PT Asuransi Takaful Keluarga cabang Surabaya terdapat fenomena dimana pimpinan mampu mengarahkan para karyawan dengan pembekalan spiritualitas lewat doa dan membaca al-quran yang dilakukan secara bersama-sama oleh seluruh karyawan sebelum memulai pekerjaan, dan siraman rohani berupa pengajian/ceramah agama setiap minggu sekali pada hari jumat. Kemudian juga adanya keinginan karyawan dalam membantu karyawan lain yang terbukti apabila ada salah satu karyawan yang sedang lembur seringkali temannya membantu menyelesaikan pekerjaan walaupun tidak dapat uang lembur. Pelayanan dari para karyawan terhadap nasabah juga terlihat sangat professional dan akrab yang terbukti dari hubungan kekeluargaan yang dekat dari setiap karyawan dengan nasabah dan penanganan asuransi yang cepat. Dari fenomena yang terjadi di atas, gaya kepemimpinan bagaimana yang dapat membuat rasa kekeluargaan pada karyawan kantor pemasaran PT. Asuransi Takaful Keluarga cabang Surabaya sehingga membentuk komitmen organisasi.

Persaingan yang semakin ketat dengan perusahaan asuransi lainnya, membuat PT. Asuransi Takaful Keluarga berupaya untuk terus meningkatkan komitmen organisasi. Sebagai perusahaan asuransi syariah, Takaful beroperasi dengan konsep tolong menolong dalam kebaikan dan ketakwaan, sebagaimana telah digariskan di dalam AL-QUR'AN. " Dan tolong menolonglah kamu dalam kebaikan dan takwa." (QS: Al-Maidah: 2). Melalui landasan ini, Takaful menjadikan semua karyawan sebagai satu keluarga besar yang akan saling melindungi dan secara bersama menanggung resiko keuangan dari musibah yang mungkin terjadi di antara mereka.

Berdasarkan hal tersebut, maka dikemukakan rumusan masalah: (1) Apakah spiritual leadership mempunyai pengaruh signifikan terhadap calling pada PT Asuransi Takaful Keluarga. (2) Apakah spiritual leadership mempunyai pengaruh signifikan terhadap membership pada PT Asuransi Takaful Keluarga. (3) Apakah calling mempunyai pengaruh signifikan terhadap organizational commitment pada PT Asuransi Takaful Keluarga. (4) Apakah membership mempunyai pengaruh signifikan terhadap organizational commitment pada PT Asuransi Takaful Keluarga. Penelitian ini bertujuan untuk menganalisis besarnya pengaruh: (1) spiritual leadership terhadap calling, (2) spiritual leadership terhadap membership (3) calling terhadap organizational commitment, (4) membership terhadap organizational commitment. 


\section{TINJAUAN PUSTAKA}

Kepemimpinan

Definisi kepemimpinan telah dikemukakan oleh Robbins (1996: 354) yang mengatakan bahwa kepemimpinan adalah kemampuan mempengaruhi suatu kelompok ke arah pencapaian tujuan.Teori dari kepemimpinan pada umumnya merupakan perbedaan konseptual antara manajemen sebagai kontrol (management as control) dan pemimpin sebagai motivator (leadership as motivation) (Conger \& Kanungo, 1988; Maddock \& Fulton, 1998). Kepemimpinan dan manajemen terlibat dalam penentuan arah dari organisasi. Meskipun demikian, manajemen merupakan planning, organizing, staffing, directing dan controlling, sedangkan leadership merupakan proses memotivasi seseorang untuk berubah (Kotter, 1990).

Kepemimpinan merupakan seni dalam memobilisasi orang lain untuk bekerja keras menuju tujuan. Dengan perspektif kepemimpinan ini, maka perlu adanya memotivasi anggota dengan membuat vision dalam jangka panjang yang diinginkan dan menarik perhatian serta perubahan yang positif.

Spiritual Survival

Fleischman (1994) dan Maddock \& Fulton (1998) telah merumuskan dua aspek dari work place spirituality berupa calling dan membership sebagai dua hal yang diperlukan dalam dimensi dari spiritual survival. Kedua aspek ini saling berhubungan satu sama lain, secara bersama dengan human experience pada umumnya. Filley, House \& Kerr di dalam Fry (2003: 704) mendefinisikan calling sebagai panggilan jiwa yang luar biasa untuk memperoleh arti dan tujuan hidup dalam melakukan sebuah perubahan dengan melayani orang lain. Istilah calling telah lama digunakan untuk mendefinisikan karakteristik dari seorang profesional, calling merupakan transendent visión dari sebuah bentuk pelayanan karyawan kepada pelanggan. Hal tersebut memungkinkan karyawan menunjukkan intrinsik motivasi melalui calling dengan "doing what it takes" ke "spread the organization message" yang berhubungan dengan kualitas hidup dan pelayanan (Fry, 2006). Adapun karakteristik dari calling menurut Fry (2003): (1) Pekerjaan yang dilakukan sangat penting bagi dirinya. (2) Pekerjaan yang dilakukan dapat memberi sebuah perubahan positif dalam kehidupan. (3) Aktivitas pekerjaan secara pribadi sangat berarti bagi dirinya.

Menurut William dalam Fry (2003: 704) pendiri dari modern psychology mendefinisikan membership sebagai kebutuhan dasar manusia yaitu ingin dimengerti dan ingin dihargai. Memiliki perasaan ingin dimengerti dan ingin dihargai merupakan persoalan yang penting dalam hubungan timbal balik dan interaksi hubungan sosial. Adapun karakteristik dari membership adalah: (1) Memiliki perasaan ingin dimengerti dalam komunitas organisasi. (2) Memiliki perasaan ingin dihargai dalam komunitas organisasi.

Religion versus spirituality

Menurut Lama (1999) menjelaskan perbedaan yang mendasar antara spiritual dengan religion sebagai berikut:

"Religion I take to be concerned with faith in the claims of one faith tradition or another, an aspect of which is the acceptance of some form of heaven or nirvana. 
Connected with this are religious teachings or dogma, ritual prayer, and so on. Spirituality I take to be concerned with those qualities of the human spirit - such as love and comparison, patience tolerance, forgiveness, contentment, a sense of responsibility, a sense of harmony- which bringhappiness to both self and others".

Dari perspective ini, spirituality diperlukan untuk religion, tapi religion tidak diperlukan dalam spirituality. Workplace spirituality dan kepemimpinan spiritual dapat termasuk atau tidak termasuk dari teori dan praktek religius.

\section{Spiritual Leadership}

Arti spiritualitas dilingkungan kerja berhubungan erat dengan teori Kaizen yaitu teori manajemen yang berpusat pada peningkatan dan perbaikan proses dibandingkan dengan mendapatkan hasil tertentu. Aburdene (2005) berpendapat "tujuan utama dari pengelolaan organisasi dengan nilai spiritual (termasuk pemenuhan kebutuhan karyawan tentang semangat dan arti hidup, pemahaman kembali tentang nilai, moral, kebaikan dan kemudahan pencarian nilai spiritual) menjawab segala permasalahan kontemporer dan mengembangkan kehidupan spiritual".

Menurut Fry (2003) kepemimpinan spiritual merupakan pembentukan values, attitude, behavior yang dibutuhkan untuk memotivasi diri sendiri dan orang lain secara intrinsic motivation sehingga menggapai rasa spiritual survival melalui calling dan membership. Adapun ciri-ciri dari kepemimpinan spiritual adalah: (1) Vision merupakan bagian terpenting yang menarik perhatian untuk melihat apa yang diinginkan oleh organisasi dalam jangka pendek dan jangka panjang. "Vision merupakan sebuah gambaran dimasa yang akan datang secara tersembunyi (implicit) atau sangat jelas (explicit) dikarenakan mengapa seseorang berjuang untuk menggapai masa depan" (Kotter, 1996: 68). (2) Altruistic Love, misi merupakan alasan mengapa sebuah organisasi ada dan merupakan sebuah dasar penetapan dalam membuat vision.

Dalam kepemimpinan spiritual, altruistic love didefinisikan sebagai perasaan yang utuh, harmonis, kesejahteraan, kepedulian dan apresiasi untuk diri dan sesama. Berdasarkan definisi tersebut maka didalamnya mengandung nilai sabar, ramah, tidak iri hati, rendah hati, pengendalian diri, dipercaya, setia dan kejujuran. (3) Hope/Faith menurut kamus Webster's definisi dari faith ialah "kepastian dari sesuatu yang diharapkan, sanksi dari sesuatu yang tidak terlihat". Kepercayaan lebih dari sekedar harapan atau sebuah pengharapan atas sesuatu yang diinginkan. Ini merupakan sanksi yang tidak dapat dibuktikan oleh bukti fisik. Hope merupakan keinginan atas sebuah pengharapan yang dipenuhi. Orang yang memiliki kepercayaan atau harapan memiliki tujuan kemana mereka akan pergi, dan bagaimana cara mencapainya, mereka akan dapat menghadapi perlawanan, pertahanan dan penderitaan dalam mencapai tujuan (MacArthur, 1998). Dengan demikian kepercayaan atau harapan merupakan dasar dari pendirian visi/ tujuan/ misi organisasi yang akan dipenuhi.

Sehingga pada lingkaran instrinsic motivation yang berdasar pada vision, altruistic love dan hope/faith ini menghasilkan sebuah perasaan pada spiritual survival melalui calling dan membership sehingga pada akhirnya mengakibatkan peningkatan kinerja karyawan yang positif. 
Menurut Fry (2003: 714) mendefinisikan organizational commitment merupakan orang yang memiliki perasaan calling dan membership yang akan menjadi saling berhubungan untuk lebih setia, dan ingin tinggal pada sebuah organisasi yang memiliki budaya berdasar pada nilai-nilai cinta (altruistic love). Hal ini dapat ditunjukkan dengan: (1) Memiliki perasaan menjadi keluarga dalam sebuah organisasi. (2) Memiliki perasaan bahwa permasalahan dalam organisasi merupakan permasalahan bersama. (3) Memiliki perasaan senang dan bangga untuk dapat mengembangkan karir dalam organisasi. (4) Menceritakan pada orang lain bahwa/tentang organisasi sebagai tempat yang menyenangkan untuk bekerja.

Fry (2003) yang menyatakan kepemimpinan spiritual merupakan pembentukan values, attitude, behavior yang dibutuhkan untuk memotivasi diri sendiri dan orang lain secara intrinsic motivation sehingga menggapai rasa spiritual survival melalui calling/meaning dan membership sehingga berdampak pada pengendalian organizational commitment, productivity dan firm performance. Sikap professional yang dimiliki setiap karyawan berdasarkan perasaan calling akan meningkatkan perasaan menjadi lebih bermakna kepada orang lain dan lingkungan organisasi serta dirinya sendiri (Baumeister, 1991). Orang akan melakukan apa saja demi sebuah panggilan jiwa (calling) yang sangat berbeda dari pekerjaan atau karier (Baumeister, 1991).

Fairholm (1998) yang menyatakan bahwa organizational commitment adalah para karyawan yang memiliki perasaan calling dan membership kemudian menjadi saling berhubungan untuk lebih setia (loyalty), dan ingin tinggal (commitment) pada sebuah organisasi yang memiliki budaya berdasar pada nilai-nilai cinta (altruistic love).

\section{HIPOTESIS}

Berdasarkan perumusan masalah dan rerangka teoritis diatas dapat ditarik suatu hipotesis sebagai berikut: (1) Spiritual leadership mempunyai pengaruh signifikan terhadap calling pada PT Asuransi Takaful Keluarga. (2) Spiritual leadership mempunyai pengaruh signifikan terhadap membership pada PT Asuransi Takaful Keluarga. (3) Calling mempunyai pengaruh signifikan terhadap organizational commitment pada PT Asuransi Takaful Keluarga. (4) Membership mempunyai pengaruh signifikan terhadap organizational commitment pada PT Asuransi Takaful Keluarga.

Berdasarkan pendapat Fry (2003: 694) beberapa faktor Model analisis dalam penelitian ini merupakan turunan dari kajian teoritis yang telah dikemukakan di depan, yang secara konseptual menyatakan bahwa variabel-variabel kepemimpinan spiritual memiliki pengaruh terhadap organization commitment melalui calling dan membership sebagai variabel intervening antara variabel-variabel kepemimpinan spiritual dengan organization commitment. Dengan demikian berdasarkan latar belakang dan rerangka teoritis, maka dapat dijabarkan model analisis seperti Gambar 1.

\section{METODE PENELITIAN}

Identifikasi Variabel

Penelitian ini menggunakan pendekatan yang bersifat kuantitatif. Dengan menggunakan sampel karyawan (sumber data primer) pada kantor pemasaran PT. Asuransi Takaful 
Keluarga dimana unit analisisnya adalah individu dan menggunakan metode sampling acak (random sampling), yaitu responden diberikan beberapa pertanyaan dalam bentuk kuesioner yang terkait dengan karakteristik spiritual leadership, calling, membership dan organization commitment. Berdasarkan hipotesis yang telah diajukan, maka variabelvariabel yang akan di analisis terdiri dari (1) Variabel laten eksogen yaitu Spiritual Leadership dengan secondary order laten: vision, altruistic love dan hope/faith (2)Variabel Laten Endogen Penengah yaitu Calling dan Membership(3) Variabel Laten Endogen yaitu Organizational commitment dan (4) Variabel Manifest adalah variabel yang digunakan untuk menjelaskan dan mengukur varibel laten, dalam penelitian ini variabel manifest/indikator merupakan survey pertanyaan berupa kuesioner yang berhubungan dengan variabel-variabel laten.

Definisi Operasional

Dalam penelitian ini variabel yang digunakan dikelompokkan dalam dua variabel, yaitu variabel laten eksogen dan endogen.

Variabel eksogen terdiri atas:

\section{Gambar 1}

\section{Model Analisis Kepemimpinan Spiritual}

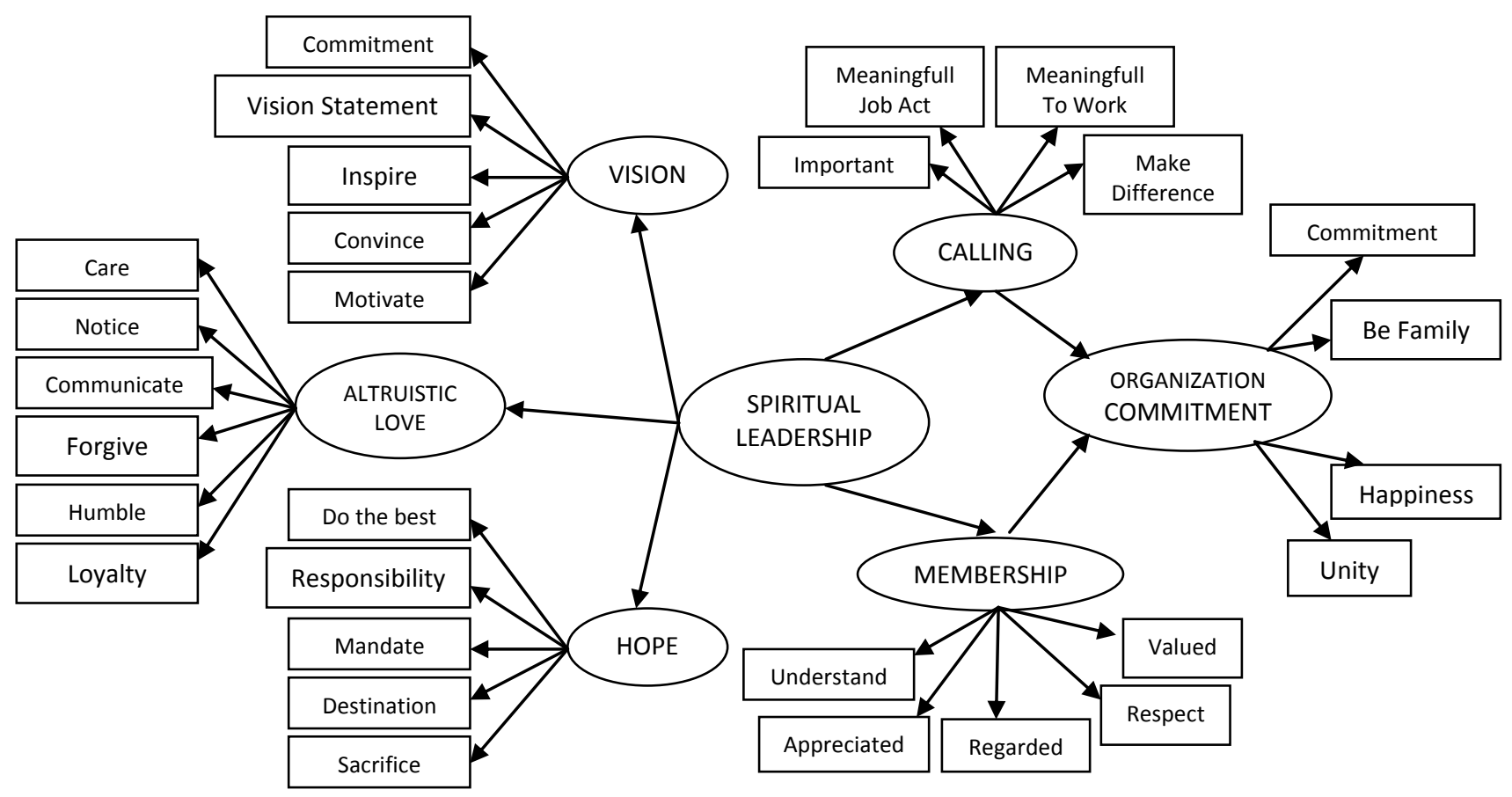

Spiritual Leadership (X)

Kepemimpinan spiritual merupakan variabel laten yang kedua setelah masing-masing varabel laten pertama berupa karakteristik Spiritual Leadership (X1-X3) dimana tiap komponen terdapat beberapa indikator.

Vision (X1). Dalam penelitian ini yang dimaksud dengan vision merupakan persepsi karyawan terhadap kemampuan pimpinan dalam menentukan tujuan organisasi baik 
jangka pendek maupun jangka panjang. Selain itu juga mendefinisikan jati diri organisasi dan apa saja yang dilakukan oleh organisasi.

Altruistic Love (X2). Altruistic Love dalam penelitian ini merupakan persepsi karyawan terhadap sikap pimpinan dalam hubungan keharmonisan antara atasan dengan bawahan dan sesama bawahan yang diwujudkan melalui perhatian. Selain itu juga kepedulian dan apresiasi untuk diri sendiri dan sesama karyawan.

Hope/Faith (X3). Dalam penelitian ini, Hope/Faith merupakan pengharapan karyawan kepada pimpinan untuk memenuhi visi dan misi perusahaan.

Calling (Z1). Calling merupakan sebuah persepsi karyawan atas pekerjaan sebagai bagian yang dapat memotivasi diri sehingga menjadi lebih berarti dan membuat sebuah perubahan.

Membership (Z2).Dalam penelitian ini berarti sebuah keinginan/ keyakinan/ pengharapan karyawan untuk ingin dimengerti dan dihargai sehingga merasa ada pada satu keluarga besar dalam lingkungan perusahaan.

Organizational Commitment (Y). Dalam penelitian ini merupakan refleksi dari seberapa besar kesetiaan atau keterikatan karyawan terhadap perusahaan.

Teknik Pengambilan dan Jumlah Sampel

Populasi penelitian ini adalah seluruh karyawan bagian marketing di PT. Asuransi Takaful Keluarga cabang Surabaya dengan pengumpulan data menggunakan kuesioner yang disebarkan berjumlah 50 orang, sehingga penelitian ini akan menggunakan populasi atau sensus. Teknik analisis yang digunakan dalam penelitian ini ialah dengan menggunakan Partial Least Square (PLS). Partial Least Square merupakan factor indeterminacy metode analisis yang powerfull oleh karena dapat diterapkan pada semua skala data, tidak membutuhkan banyak asumsi dan ukuran sampel tidak harus besar. PLS selain dapat digunakan sebagai konfirmasi teori juga dapat digunakan untuk membangun hubungan yang belum ada landasan terorinya atau untuk pengujian proposisi. Pendekatan PLS adalah dstribution free (tidak mengasumsikan data berdistribusi tertentu, dapat berupa nominal, kategori, ordinal interval dan rasio). PLS dapat digunakan untuk mengkonfirmasi teori dan menjelaskan ada atau tidaknya hubungan antar variable laten. Algoritma dalam PLS menggunakan series ordinary least square.

\section{Tabel 1}

Validity dan Reliability Variabel

\begin{tabular}{|l|r|r|r|l|l|l|}
\hline \multicolumn{1}{|c|}{ Variable } & \multicolumn{1}{c|}{$\begin{array}{c}\text { Scale } \\
\text { Mean }\end{array}$} & $\begin{array}{c}\text { Scale } \\
\text { Variance }\end{array}$ & $\begin{array}{c}\text { Corrected } \\
\text { Item }\end{array}$ & Validity & Alpha & Reliability \\
\hline Vision 1 & 16,08 & 5,5853 & 0,4747 & Valid & 0,7859 & Reliable \\
\hline Vision 2 & 15,78 & 6,1751 & 0,5514 & Valid & 0,7859 & Reliable \\
\hline Vision 3 & 15,66 & 6,229 & 0,6787 & Valid & 0,7859 & Reliable \\
\hline Vision 4 & 15,28 & 7,3894 & 0,5384 & Valid & 0,7859 & Reliable \\
\hline
\end{tabular}




\begin{tabular}{|l|r|r|r|l|r|l|} 
Vision 5 & 15,44 & 6,2922 & 0,7177 & Valid & 0,7859 & Reliable \\
\hline ALTRUIS1 & 23,46 & 10,7841 & 0,4147 & Valid & 0,7955 & Reliable \\
\hline ALTRUIS2 & 22,98 & 9,9792 & 0,7044 & Valid & 0,7955 & Reliable \\
\hline ALTRUIS3 & 23,06 & 9,5269 & 0,7063 & Valid & 0,7955 & Reliable \\
\hline ALTRUIS4 & 23,58 & 9,922 & 0,5226 & Valid & 0,7955 & Reliable \\
\hline ALTRUIS5 & 22,86 & 10,9392 & 0,3948 & Valid & 0,7955 & Reliable \\
\hline ALTRUIS6 & 23,04 & 9,9984 & 0,7106 & Valid & 0,7955 & Reliable \\
\hline ALTRUIS7 & 23,5 & 11,3163 & 0,3032 & Valid & 0,7955 & Reliable \\
\hline HOPE1 & 16,84 & 4,1371 & 0,3907 & Valid & 0,7556 & Reliable \\
\hline HOPE2 & 16,62 & 3,7914 & 0,6615 & Valid & 0,7556 & Reliable \\
\hline HOPE3 & 16,92 & 3,6261 & 0,5025 & Valid & 0,7556 & Reliable \\
\hline HOPE4 & 16,56 & 4,3331 & 0,4271 & Valid & 0,7556 & Reliable \\
\hline HOPE5 & 16,58 & 3,8812 & 0,7016 & Valid & 0,7556 & Reliable \\
\hline CALL1 & 7,94 & 1,078 & 0,6513 & Valid & 0,7349 & Reliable \\
\hline CALL2 & 7,98 & 1,1629 & 0,6093 & Valid & 0,7349 & Reliable \\
\hline CALL3 & 8,28 & 1,2261 & 0,433 & Valid & 0,7349 & Reliable \\
\hline MEMBER1 & 4,1 & 0,5408 & 0,5869 & Valid & 0,7395 & Reliable \\
\hline MEMBER2 & 3,98 & 0,5098 & 0,5869 & Valid & 0,7395 & Reliable \\
\hline KOMIT1 & 11,64 & 3,0922 & 0,7768 & Valid & 0,8678 & Reliable \\
\hline KOMIT2 & 11,76 & 3,329 & 0,8138 & Valid & 0,8678 & Reliable \\
\hline KOMIT3 & 11,84 & 4,3412 & 0,7094 & Valid & 0,8678 & Reliable \\
\hline KOMIT4 & 12,04 & 3,3861 & 0,6656 & Valid & 0,8678 & Reliable \\
\hline
\end{tabular}

Tabel 2

Hasil Validitas Konvergen Variabel Spiritual Leadership

\begin{tabular}{|l|l|c|c|c|c|c|}
\hline \multicolumn{2}{|c|}{ VARIABEL } & $\begin{array}{c}\text { LOADIN } \\
G\end{array}$ & MEAN & STD DEVIATION & T-STATISTIC \\
\hline Spiritual Leadership (X) & $\Rightarrow$ & Vision (X1) & 0.710 & 0.713 & 0.086 & 8.283 \\
\hline Spiritual Leadership (X) & $\Rightarrow$ & $\begin{array}{c}\text { Altruistic } \\
\text { Love (X2) }\end{array}$ & 0.869 & 0.863 & 0.034 & 25.184 \\
\hline Spiritual Leadership (X) & $\Rightarrow$ & Hope (X3) & 0.790 & 0.809 & 0.045 & 17.631 \\
\hline
\end{tabular}

\section{ANALISIS DAN PEMBAHASAN}

Karakteristik Responden Penelitian

Karakteristik responden berdasarkan jenis kelamin menunjukkan bahwa karyawan pria sebanyak 28 orang $(56 \%)$ dan 22 orang (44\%) adalah wanita. Persentase responden berdasarkan usia kurang dari 20 tahun sebanyak 1 orang (2\%), usia 20-25 tahun sebanyak 6 orang (12\%), usia 26-30 tahun sebanyak 22 orang (44\%), usia 31-35 tahun sebanyak 7 orang (14\%) dan usia antara 36-40 tahun sebanyak 14 orang (28\%). Persentase responden berdasarkan lama bekerja kurang dari 1 tahun sebanyak 11 orang (22\%), 1-5 tahun sebanyak 29 orang (58\%), dan bekerja 6 - 10 tahun ada 10 orang (20\%). Persentase responden berdasarkan pendidikan adalah 34 orang (68\%) untuk berpendidikan sarjana S1, 
Sedangkan yang lulusan sarjana muda atau diploma sebesar 13 orang (26\%) dan yang lulusan SMU ada sebanyak 3 orang (6\%).

Uji Validitas dan Reliabilitas

Validitas sebuah alat ukur diketahui dengan cara mengkorelasikan skor masing-masing item dengan skor total item. Item atau indikator dinyatakan valid jika $r$ hitung atau nilai corrected item total correlation mempunyai nilai lebih besar dari $r$ standar yaitu 0,3 (Solimun, 2005).

Berdasarkan tabel 1, besarnya corrected item total correlation untuk kelima indikator variabel vision, altruistic love, hope, calling, membership, organizational commitment diatas 0,3 sehingga seluruh indikator dinyatakan valid

Tahap Measurement

Validitas Konvergen

Convergen validity dari model pengukuran dengan refleksif indikator dinilai berdasarkan korelasi antara item score/ component score dengan construct score yang dihitung dengan PLS. Ukuran refleksif individual dikatakan tinggi jika berkorelasi lebih dari 0.70 dengan konstruk yang ingin diukur. Namun demikian untuk penelitian tahap awal dari pengembangan skala pengukuran nilai loading 0,5 sampai 0,60 dianggap cukup (Chin, 1998). Disamping itu untuk mengetahui indikator merupakan konstruk dari variable tersebut dapat dilihat melalui nilai Tstatistic lebih besar dari 1,96 (Ghozali 2008).

Spiritual Leadership

Spiritual Leadership ini merupakan second order refleksif konstruk dari tiga dimensi yaitu vision, altruistic love dan hope. Pendekatan untuk menganalisis second order factor seperti yang disarankan oleh Wold (cf Lohmoller, 1989 dan Chin et al, 1996) adalah menggunakan repeated indicators approach atau juga dikenal dengan hierarchical component model. Konstruk spiritual leadership ini disusun dari tiga dimensi yaitu vision, altruistic love dan hope. Berdasarkan tabel 2 pengaruh dari second order konstruk Spiritual Leadership terhadap dimensi first order konstruk Vision, Altruistic Love dan Hope dengan nilai T-Statistik diatas 1,96. Jadi dapat disimpulkan bahwa konstruk Spiritual Leadership dibentuk oleh tiga dimensi tersebut. Dari tabel 2 juga dapat disimpulkan bahwa Altruistic Love merupakan dimensi yang paling berpengaruh pada konstruk Spiritual Leadership karena nilai loadingnya paling besar diantara tiga dimensi yang lain, yaitu sebesar 0,869. Untuk memperjelas penjelasan dari tabel 2, berikut deskripsi dari masing-masing dimensi:

Vision (X1). Berdasarkan tabel 3 menunjukkan bahwa nilai loading indikator vision lebih besar dari 0,5 dan nilai T-Statistic lebih besar dari 1,96 maka indikator-indikator vision merupakan konstruk dari variable vision. Dan nilai loading yang paling tinggi berarti indikator yang paling mendukung konstruk.

Altruitic Love (X2). Berdasarkan tabel 4 diatas terdapat nilai factor loading dari altruis 1 yang kurang dari 0,5 sehingga harus di drop dari analisis karena memiliki nilai convergent validity rendah. Setelah mendrop 9ndicator yang factor loadingnya dibawah 0,5 maka dilakukan analisis kembali. Pada tabel 5 terdapat nilai factor loading dari altruis 5 yang kurang dari 0,5 sehingga harus di drop dari analisis karena memiliki nilai convergent validity rendah. Setelah mendrop 9ndicator yang factor loadingnya dibawah 0,5 maka dilakukan analisis kembali. 
Kemudian tabel 4 menunjukkan bahwa nilai loading 10ndicator altruistic love lebih besar dari 0,5 dan nilai T-Statistic lebih besar dari 1,96 maka 10ndicator-indikator altruistic love merupakan konstruk dari variable altruistic love. Dan nilai loading yang paling tinggi berarti 10ndicator yang paling mendukung konstruk.

Hope/Faith (X3). Berdasarkan tabel 1 menunjukkan bahwa nilai loading indikator hope lebih besar dari 0,5 dan nilai T-Statistic lebih besar dari 1,96 maka indikator-indikator hope merupakan konstruk dari variable hope. Dan nilai loading yang paling tinggi berarti indikator yang paling mendukung konstruk

Tabel 3

Results of Convergent Validitity Vision

\begin{tabular}{|c|c|c|c|}
\hline INDIKATOR & LOADING & T-STATISTIC & DESCRIPTION \\
\hline Vision 1 & 0,593 & 2,859 & Valid \\
\hline Vision 2 & 0,700 & 5,136 & Valid \\
\hline Vision 3 & 0,818 & 12,008 & Valid \\
\hline Vision 4 & 0,795 & 12,693 & Valid \\
\hline Vision 5 & 0,848 & 9,185 & Valid \\
\hline
\end{tabular}

Tabel 4

Results of Convergent Validitity Altruistic Love - first analysis

\begin{tabular}{|c|c|c|c|}
\hline INDIKATOR & LOADING & T-STATISTIC & DESCRIPTION \\
\hline ALTRUIS1 & 0,481 & 1,768 & Tidak Valid \\
\hline ALTRUIS2 & 0,857 & 25,652 & Valid \\
\hline ALTRUIS3 & 0,845 & 19,456 & Valid \\
\hline ALTRUIS4 & 0,686 & 7,008 & Valid \\
\hline ALTRUIS5 & 0,500 & 3,150 & Valid \\
\hline ALTRUIS6 & 0,819 & 10,718 & Valid \\
\hline ALTRUIS7 & 0,502 & 3,336 & Valid \\
\hline
\end{tabular}

Tabel 5

Results of Convergent Validitity Altruistic Love - second analysis

\begin{tabular}{|c|c|c|c|}
\hline INDIKATOR & LOADING & T-STATISTIC & DESCRIPTION \\
\hline ALTRUIS2 & 0,871 & 32,172 & Valid \\
\hline ALTRUIS3 & 0,850 & 23,682 & Valid \\
\hline ALTRUIS4 & 0,679 & 9,566 & Valid \\
\hline ALTRUIS5 & 0,481 & 2,800 & Tidak Valid \\
\hline ALTRUIS6 & 0,820 & 13,841 & Valid \\
\hline ALTRUIS7 & 0,520 & 4,139 & Valid \\
\hline
\end{tabular}

Tabel 6

Results of Convergent Validitity Altruistic Love - third analysis

\begin{tabular}{|c|c|c|c|}
\hline INDIKATOR & LOADING & T-STATISTIC & DESCRIPTION \\
\hline ALTRUIS2 & 0,899 & 22,904 & Valid \\
\hline ALTRUIS3 & 0,868 & 15,157 & Valid \\
\hline ALTRUIS4 & 0,707 & 8,756 & Valid \\
\hline ALTRUIS6 & 0,807 & 10,078 & Valid \\
\hline
\end{tabular}




\begin{tabular}{|l|l|l|l|}
\hline ALTRUIS7 & 0,501 & 3,273 & Valid \\
\hline
\end{tabular}

Tabel 7

Results of Convergent Validitity Hope (X3)

\begin{tabular}{|c|c|c|c|}
\hline INDIKATOR & LOADING & T-STATISTIC & DESCRIPTION \\
\hline HOPE1 & 0,671 & 3,569 & Valid \\
\hline HOPE2 & 0,830 & 13,329 & Valid \\
\hline HOPE3 & 0,665 & 4,254 & Valid \\
\hline HOPE4 & 0,550 & 2,763 & Valid \\
\hline HOPE5 & 0,847 & 16,646 & Valid \\
\hline
\end{tabular}

Tahap Structural Model

Hasil pengujian partial least square dengan nilai koefisien atau standardize pada masingmasing variabel dapat dilihat pada Gambar 2 dan Tabel 10. Pada tabel 10 dapat diketahui jika variabel spiritual leadership berubah maka menyebabkan perubahan terhadap variabel calling. Tanda positif menunjukkan perubahan yang searah yaitu jika variable spiritual leadership meningkat maka variable calling akan meningkat, dan begitu sebaliknya dengan nilai standart 0,477. Jika variabel spiritual leadership berubah maka akan menyebabkan perubahan terhadap variable membership. Tanda positif menunjukkan perubahan yang searah yaitu jika variable spiritual leadership meningkat maka variable membership akan meningkat, dan begitu sebaliknya dengan nilai standart 0,438. Jika variabel calling berubah maka akan menyebabkan perubahan terhadap variable organizazional commitment. Tanda positif menunjukkan perubahan yang searah yaitu jika variable calling meningkat maka variable organizational commitment akan meningkat, dan begitu sebaliknya dengan nilai standart 0,390. Jika variabel membership berubah maka akan menyebabkan perubahan terhadap variable organizational commitment. Tanda positif menunjukkan perubahan yang searah yaitu jika variable membership meningkat maka variable organizational commitment akan meningkat, dan begitu sebaliknya dengan nilai standart 0,324 . Berdasarkan nilai standarisasi koefisien tersebut juga dapat diketahui hubungan antar variabel yang berpengaruh dominan. Hubungan antar variabel yang terbesar adalah yang menghubungkan spiritual leadership terhadap calling dengan nilai koefisien jalur sebesar 0,477 . 
Gambar 2

Hasil Pengujian Partial Least Square

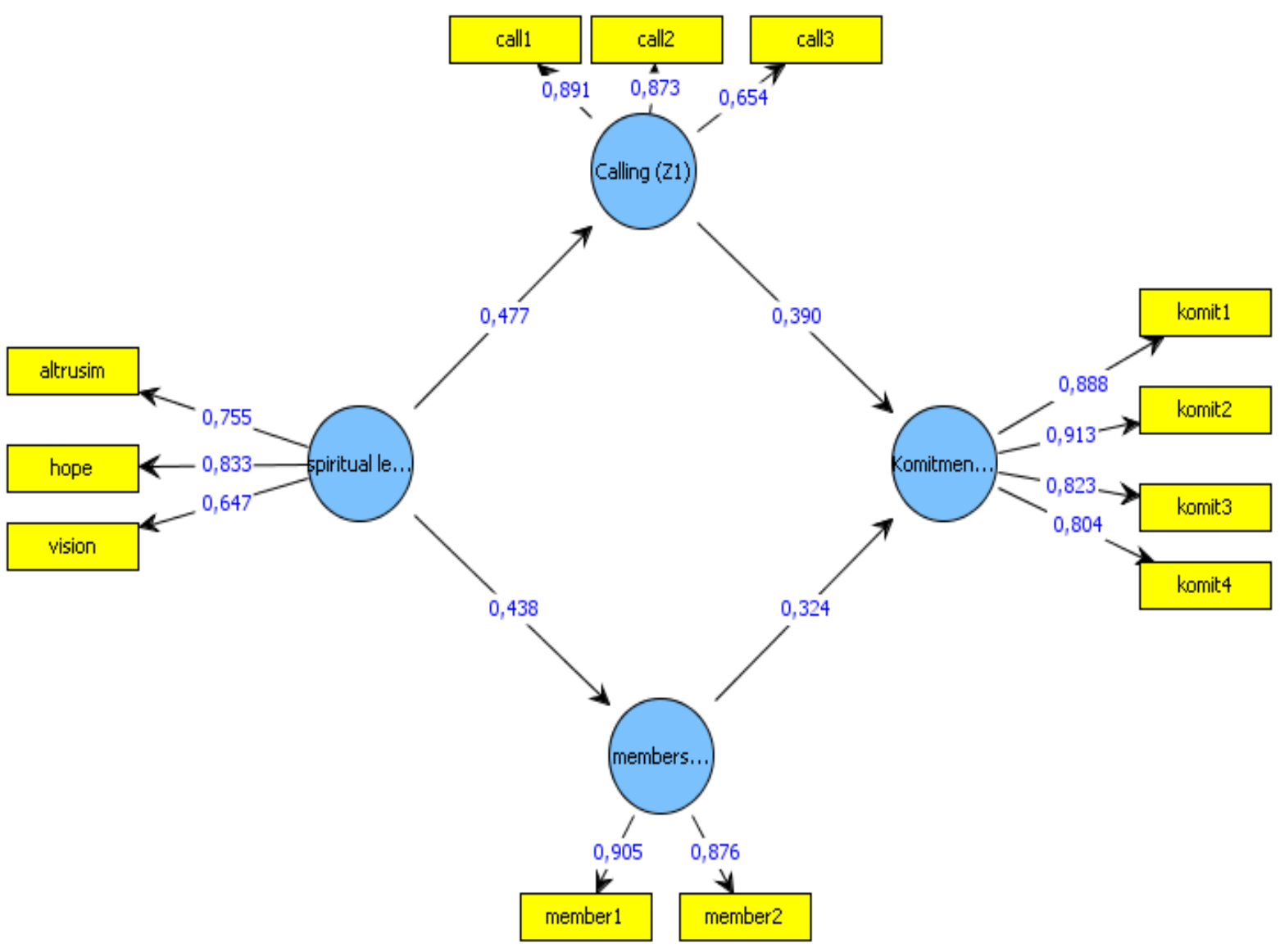

Tabel 8

Hasil Pengujian Partial Least Square Spiritual Leadership

\begin{tabular}{|c|c|c|c|}
\hline \multicolumn{3}{|c|}{ Variable } & $\begin{array}{c}\text { Standardized } \\
\text { Coefisien }\end{array}$ \\
\hline Spiritual Leadership (X) & $\Rightarrow$ & Calling (Z1) & 0,477 \\
\hline Spiritual Leadership (X) & $\Rightarrow$ & Membership (Z2) & 0,438 \\
\hline Calling (Z1) & $\Rightarrow$ & Organizational Comitment (Y) & 0,390 \\
\hline Membership (Z2) & $\Rightarrow$ & Organizational Comitment (Y) & 0,324 \\
\hline
\end{tabular}


Tabel 9

Hasil Pengujian Hipotesis

\begin{tabular}{|c|l|c|c|c|c|}
\hline \multicolumn{2}{|c|}{ VARIABLE } & T-STATISTIC & T-TABEL & Description \\
\hline $\begin{array}{c}\text { Spiritual } \\
\text { Leadership (X) }\end{array}$ & $\Rightarrow$ & Calling (Z1) & 4,109 & 1,96 & Significant \\
\hline $\begin{array}{c}\text { Spiritual } \\
\text { Leadership (X) }\end{array}$ & $\Rightarrow$ & Membership (Z2) & 3,508 & 1,96 & Significant \\
\hline Calling (Z1) & $\Rightarrow$ & $\begin{array}{c}\text { Organizational } \\
\text { Comitment (Y) }\end{array}$ & 3,180 & 1,96 & Significant \\
\hline Membership (Z2) & $\Rightarrow$ & $\begin{array}{c}\text { Organizational } \\
\text { Comitment (Y) }\end{array}$ & 2,599 & 1,96 & Significant \\
\hline
\end{tabular}

Uji Hipotesis

Pengujian hipotesis ini dilakukan dengan bootsrapping untuk menentukan nilai signifikansi untuk masing-masing factor loading baik pada first order maupun second order menggunakan program SmartPLS.

Berikut tabel dari hasil pengujian hipotesis:

Berdasarkan tabel 9 dapat dilihat bahwa variabel Spiritual Leadership terhadap Calling dengan nilai T-Statistic 4,109 dan nilai ini lebih besar dari nilai T-tabel 1,96 yang berarti ada pengaruh yang signifikan dari variabel Spiritual Leadership terhadap Calling

Pengaruh Spiritual Leadership Terhadap Calling

Hasil penelitian menunjukkan ada pengaruh langsung spiritual leadership terhadap calling pada karyawan PT. Asuransi Takaful Keluarga Kantor Pemasaran Surabaya. Semakin tinggi spiritual leadership yang dimiliki oleh pimpinan maka akan semakin tinggi pula calling/meaning yang dimiliki oleh setiap karyawan.

Oleh karena itu pimpinan PT. Asuransi Takaful Keluarga Kantor Pemasaran Surabaya menanamkan nilai-nilai spiritualitas, attitude dan behaviour yang baik di lingkungan kerja. Selain itu juga tidak hanya menekankan keuntungan dunia, namun juga keuntungan di akherat kelak. Hal ini dapat dicapai dengan keyakinan yang kuat bahwa bekerja adalah ibadah dalam pandangan agama. Oleh karena itu Asuransi Takaful Keluarga secara istiqomah atau berkelanjutan memberikan sebuah kegiatan yang bertujuan untuk menjaga niat para karyawan dalam bekerja untuk ibadah (sehingga meningkatkan perasaan calling/meaning).

Pengaruh Spiritual Leadership Terhadap Membership

Hasil penelitian menunjukkan ada pengaruh langsung antara spiritual leadership terhadap membership pada karyawan PT. Asuransi Takaful Keluarga Kantor Pemasaran Surabaya. Semakin tinggi spiritual leadership yang dimiliki oleh pimpinan maka akan semakin tinggi pula membership yang dimiliki oleh setiap karyawan. Pada penelitian ini membership diukur berdasarkan aspek perasaan ingin dimengerti dan dihargai oleh komunitas organisasi, 
pimpinan PT. Asuransi Takaful Keluarga Kantor Pemasaran Surabaya memahami akan pentingnya hubungan sosial antar karyawan yang kondusif agar terjalin ikatan batin sehingga tercapainya organizational commitment. Karena sebuah lingkungan organisasi yang kondusif tidak akan mudah tercipta tanpa campur tangan pimpinan.

Pengaruh Calling Terhadap Organizational Commitment

Hasil penelitian menunjukkan ada pengaruh langsung antara calling terhadap organizational commitment pada karyawan PT. Asuransi Takaful Keluarga Kantor Pemasaran Surabaya. Semakin tinggi perasaan calling yang dimiliki oleh karyawan maka akan semakin tinggi pula organizational commitment yang dimiliki oleh setiap karyawan. Jadi panggilan jiwa yang kuat (calling) dan hubungan spiritual dengan pekerjaan yang melampaui professionalisme atau gaji akan menyebabkan hubungan yang dalam, dan dengan demikian akan komitmen untuk satu pekerjaan (Markow \& Klenke, 2005). Dalam sejumlah penelitian telah menunjukkan bahwa komitmen karyawan berkorelasi positif dengan beberapa hasil organisasi. Sebagai contoh, karyawan yang berkomitmen untuk organisasi akan menunjukkan tingkat yang lebih rendah dalam berperilaku negatif seperti ketidakhadiran atau turnover (Cotton \& Turtle, 1986).

Berdasarkan hasil menunjukkan bahwa perasaan calling karyawan Asuransi Takaful Keluarga Kantor Pemasaran Surabaya berpengaruh significant. Hal ini mengindikasikan bahwa perasaan calling dimiliki oleh sebagian besar karyawan Asuransi Takaful Keluarga Kantor Pemasaran Surabaya sehingga berpengaruh pada organizational commitment.

Pengaruh Membership Terhadap Organizational Commitment

Hasil penelitian menunjukkan ada pengaruh langsung antara membership terhadap organizational commitment pada karyawan PT. Asuransi Takaful Keluarga Kantor Pemasaran Surabaya. Semakin tinggi perasaan membership yang dimiliki oleh keryawan maka akan semakin tinggi pula organizational yang dimiliki oleh setiap karyawan. Perasaan membership merupakan salah satu perasaan spiritualitas pada lingkungan kerja (workplace spirituality) yang penting sekali untuk dikembangkan agar hubungan sosial antar karyawan Asuransi Takaful Keluarga Kantor Pemasaran Surabaya dapat terjalin dengan harmonis, ditunjukkan berdasarkan hasil penelitian bahwa pengaruh membership cukup significant. Hal ini mengidentifikasikan bahwa membership dimiliki oleh sebagian besar karyawan Asuransi Takaful Keluarga Kantor Pemasaran Surabaya sehingga berpengaruh pada organizational commitment. Dan fakta yang ada di lapangan membuktikan bahwa adanya kerjasama yang kuat antara satu tim penjualan dengan tim penjualan yang lain dan antara sesama karyawannya. Hal ini mengantarkan Asuransi Takaful Keluarga Kantor Pemasaran Surabaya memperoleh penghargaan Asuransi Syariah Terbaik pada tahun 2003 oleh MUI.

\section{SIMPULAN DAN SARAN}

Berdasarkan hasil pengolahan data menggunakan partial least square (PLS), menunjukkan Spiritual leadership berpengaruh signifikan terhadap calling dan membership pada karyawan. Dengan hasil ini maka hipotesis pertama dan kedua penelitian terdukung. Calling 
dan Membership berpengaruh signifikan terhadap organizational commitment karyawan. Dengan hasil ini maka hipotesis ketiga dan keempat penelitian terdukung.

Saran yang perlu dilakukan oleh pihak manajemen untuk dapat mempertahankan dan meningkatkan organizational commitment karyawan yaitu pimpinan dapat menerapkan sebuah strategi pemasaran yang memanfaatkan nilai-nilai spiritual yang hidup di tengah masyarakat yang dipercayai dapat mengikat lebih erat hubungan antara perusahaan dengan konsumen dan konsumen dengan produk asuransi yang digunakan konsumen. Mengembangkan nilai-nilai spiritualitas terhadap budaya perusahaan sehingga meningkatkan rasa kekeluargaan dan kebersamaan dalam suasana kerja yang berhubungan dengan pengembangan spiritualitas seperti sholat berjamaah, pengajian rutin, bakti sosial, mengeluarkan Zakat, Infaq dan Sadaqoh (ZIS) bersama-sama, yang dilakukan secara terus-menerus (istiqomah). Membuat sebuah sistem pemantauan antar karyawan untuk menjaga nilai-nilai spiritualitas di lingkungan kerja. Dengan sistem ini diharapkan karyawan terjaga sikap dan sifat : rajin bekerja, ketertiban, rendah hati, ketabahan, keikhlasan, amanah, tawakal, suka menolong. Dengan sistem ini diharapkan karyawan dapat saling ingat mengingatkan. Dalam proses perekrutan karyawan hendaknya pihak manajemen lebih menanamkan nilai-nilai spiritualitas yang ada pada perusahaan kepada calon karyawan. Hal ini dilakukan untuk menjaga bahkan meningkatkan nilai-nilai spiritualitas yang ada pada PT. Asuransi Takaful Keluarga Kantor Pemasaran Surabaya.

\section{DAFTAR PUSTAKA}

Aburdene, Patricia. 2005. Megatrends 2010: The Rise of Concious Capitalism. Canada: Hampton Roads Publishing Company Inc.

Arikunto, S., 2002, 'Prosedur penelitian suatu praktek, Jakarta, Rineka Cipta.

Ashmos, D., \& Duchon, D. (2000). 'Spirituality at work: a conceptualization and measure', Journal of Management Inquiry, 9, 134-145.

Baumeister, R. F. 1991. Meanings of life. New York: Guilford Press.

Chin, W.W. 1998. 'The Partial Least Squares Approach for Structural Equation Modelling' In Marcoulides, G.A. (ed). Modern Method for Business Research. Mahwah. Nj.Erlbaum.

Chin, W.W. 1998. 'The Partial Least Squares Latent Variable Modelling Approach For Measuring Interaction Effects: ' In Marcoulides, G.A. (ed). Modern Method for Business Research. Mahwah. Nj.Erlbaum.

Cotton, J and Tuttle, J, 1986, 'Employee turnover: A meta-analysis and review with implication for research', Academy of Management Review, 11 (1), 55-70.

Elgin, D., \& LeDrew, C. (1997). 'Global consciousness change: Indicators of an emerging paradigm', San Anselmo, CA: Millennium Project

Fairholm, G. W. 1998. 'Perspectives on leadership: From the science of management to its spiritual heart', Westport, CT: Praeger.

Fleischman, P. R. 1994. The healing spirit: Explorations in religion and psychotherapy. Cleveland, OH: Bonne Chance Press.

Fry, Louis W. 2003. 'Toward a Theory of Spiritual Leadership', The Leadership Quarterly. No.14: 693-727. 
Fry, Louis W, Laura L Matherly. 2006. Spiritual Leadership and Organizational Performance: An Exploratory Study. Texas: Tarleton University Texas.

Ghozali, Imam. 2006. Structural Equation Modelling - Metode Alternatif dengan Partial Least Square (PLS). Semarang. Badan Penerbitan Universitas Diponegoro.

Jablonski, M. A. (2001), 'The implications of student spirituality for student affairs practice' New Directions for Student Services, no. 95. San Francisco: Jossey-Bass.

Kotter, J. P. 1990. The leadership factor. New York: Free Press.

Kotter, J. P. 1996. Leading change. Boston: Harvard Business School Press.

Lama, Dalai XIV. 1999. Ethics for the new millennium. New York: Putnam.

MacArthur, J. F. 1998. In the footsteps of faith. Wheaton, IL: Crossway Books.

Maddock, R. C., \& Fulton, R. L. 1998. Motivation, emotions, and leadership: The silent side of management. Westport, CT: Quorum Books.

Markov, F \& Klenke K. 2005. The Effect of Personal Meaning and Calling on Organizational Commitment: An Empirical Investigation of Spiritual Leadership. The International Journal of Organizational Analysis. Vol.13, No.1,pp.8-27.

Robbins, Stephen P. 1996, 'Organization Behavior: Concept, Controversies, Applications', New Jersey: Prentice-Hall International, Inc.

Solimun, 2005, 'Structural Equation Modelling (SEM)', Malang, Universitas Brawijaya. 